\title{
The influence of technologically boron-modification surface layer on the friction processes in sliding pairs of combustion engine
}

\begin{abstract}
The aim of the present work is to determine the influence of borided surface layers on the friction parameter in the work of sliding pairs in the I.C. engine. The tribological evaluation included pack-borided and laser-borided surface layers deposited on rocker arm, piston pin and pin of crankshaft. The tests were performed in the generator set equipped with one-cylinder 4-stroke carburettor Robin Subaru engine. The wear of the elements of the combustion engine demonstrated that the process of boronizing has an important influence on the decrease of wear of the borided element of the friction pair.
\end{abstract}

Keywords: surface roughness; wear resistance; borides; internal combustion engine

\section{Wpływ technologicznie uksztaltowanej warstwy powierzchniowej z borem na procesy tarcia w parach ciernych silnika spalinowego}

\begin{abstract}
W pracy przedstawiono wptyw modyfikacji borem elementów par ciernych silnika spalinowego w warunkach eksploatacyjnych na ksztaltowanie struktury geometrycznej i zużycie warstw powierzchniowych. Badania przeprowadzono w parach ciernych 4-suwowego silnika gaźnikowego Robin-Subaru EX-17: dźwignia zaworu-krzywka, sworzeń tłokowykorbowód-czop wału korbowego. Wyniki badań pozwalają stwierdzić, że modyfikacja warstw powierzchniowych borem $w$ węzłach ciernych silnika spalinowego może zapewnić korzystniejsze warunki tarcia niż stosowane obecnie technologie obróbki powierzchniowej.
\end{abstract}

Słowa kluczowe: borowanie, chropowatość powierzchni, zużycie, silnik spalinowy

\section{Introduction}

In the construction of a motor vehicle there are a great number of friction pairs working under exceptionally hard conditions of loading and they are liable to the processes of wear through friction. The greatest number of friction pairs can be found in a combustion engine and despite lubrication under pressure, liquid lubrication does not appear throughout the work cycle of the engine, and in the case of many friction pairs the most prevalent is mixed friction [1]. In order to ensure that these elements have the required resistance to wear, an appropriate surface treatment is performed. Two major classes of treatments available for enhancing the surface properties are thermal and thermochemical. Boronizing is a thermochemical surface hardening treatment, which enriches boron in the material surface by diffusion of boron atoms into the surface of the material. Diffusion of boron into the surface of various metals and alloys results in the formation of borides which provide extremely hard (up to $2000 \mathrm{HV}$ ), wear and corrosion resistant surface [2-4].

The current boronizing processes allow obtaining surface layers of high hardness and high resistance to corrosion and wear, with low brittleness and no tendencies towards cracking [5-7]. However, the operation characteristics of these layers depend on the chemical composition, the structure of the surface layer, the method and parameters of their production, and relevant thermal treatment. The modification of the surface layer with boron should be selected on the basis of the required operating characteristics and the operating conditions of the sliding pair $[6,8]$. Thus, it is crucial to determine the

\section{Wstęp}

W konstrukcji pojazdu samochodowego występuje wiele węzłów ciernych pracujących w wyjątkowo ciężkich warunkach obciążenia; narażone są one na intensywne procesy zużycia wskutek tarcia. Najwięcej węzłów ciernych występuje w silniku spalinowym i pomimo realizowanego wymuszonego smarowania, smarowanie płynne w parach ciernych występuje nie w całym okresie pracy silnika, a w przypadku wielu węzłów ślizgowych dominuje tarcie mieszane [1]. W celu zapewnia tym elementom wymaganej odporności na zużycie przeprowadza się odpowiednią obróbkę powierzchniową. Do najczęściej stosowanych metod modyfikacji warstwy powierzchniowej wykorzystuje się procesy obróbki cieplnej i cieplno-chemicznej. W procesach obróbki cieplno-chemicznej, poprzez dyfuzję można wprowadzić do obrabianego materiału bor, co pozwala na uzyskanie warstwy powierzchniowej o dużej twardości (powyżej $2000 \mathrm{HV}$ ), odpornej na korozję i zużycie ścierne [2-4].

Stosowane obecnie procesy modyfikacji borem pozwalają uzyskać warstwy powierzchniowe o dużej twardości oraz odporności na zużycie i korozję, przy małej kruchości i braku skłonności do pękania [5-7]. Cechy eksploatacyjne tych warstw zależą głównie od składu chemicznego, struktury warstwy powierzchniowej, metody wytwarzania, parametrów procesu technologicznego i odpowiedniej obróbki cieplnej. Badania wykazują, że w procesie wytwarzania warstw powierzchniowych modyfikowanych borem należy również uwzględnić wpływ czynników występujących podczas eksploatacji węzła ślizgowego 
influence the boron modification of the sliding pair elements has on the operating conditions and wear.

\section{Experimental}

In the performance of the engine tests, the following pairs of combustion engine were selected: rocker arm-camshaft, piston pin-connecting rod and pin of crankshaft-connecting rod (its large and small ends function as bearings) (Fig. 1) [9]. Boron-modified surface layers were made on the elements of friction pairs. In the slide pairs: rocker arm with camshaft and piston pin with connecting rod, the process of boronizing in powder was applied to the rocker arm and piston pin. The elements were pack borided in the temperature of $950^{\circ} \mathrm{C}$ in the time of $8 \mathrm{~h}$, and then were isothermally hardened. In the boronizing process, powder of the following composition was used: $\mathrm{B}_{4} \mathrm{C}(30 \%), \mathrm{Al}_{2} \mathrm{O}_{3}(68 \%), \mathrm{NH}_{4} \mathrm{Cl}$, and $\mathrm{NaF}$. In the pair pin of crankshaft with connecting-rod, the surface layer of crankshaft was boron-modified using the method of melting by laser beam. The pin of crankshaft was laser-borided, with the use of $\mathrm{CO}_{2}$ laser (power of beam $\mathrm{P}=2 \mathrm{~kW}$, spot diameter $\mathrm{d}=4 \mathrm{~mm}$, energy density $160 \mathrm{~W} / \mathrm{mm}^{2}$, speed of the laser beam on the surface $\mathrm{v}=16 \mathrm{~mm} / \mathrm{s}$, shielding gas-argon). The boronizing process consisted of covering the samples with the layer of amorphous boron and liquid glass, and melting with the laser beam. The combustion engine was lubricated with 5W/40 Lotos Synthetic engine oil.

The engine tests were performed in the generator set equipped with one-cylinder 4-stroke carburettor Robin Subaru engine (rated output $2.6 \mathrm{~kW} / 3000 \mathrm{rpm}$, max. torque $11.3 \mathrm{~N} \cdot \mathrm{m} / 2500 \mathrm{rpm}$ ). The generator set was loaded during its work by means of an electric resistance element of constant power of $2000 \mathrm{~W}$. The tests were performed in the cycle of 2000 hours, comprising the periods of constant work for 100 hours and the break periods resulting from the suggested times of the periodical engine service. In the break periods for the engine service lasting 200, 500, 1000, and 2000 hours, measurements of wear of the friction pairs of
$[6,8]$. Dlatego istotne jest określenie wpływu modyfikacji warstwy powierzchniowej borem na procesy tarcia w węźle ślizgowym w warunkach smarowania i uzależnioną z tym trwałość pary ciernej.

\section{Opis badań}

Do realizacji badań eksploatacyjnych wytypowano następujące węzły ślizgowe silnika spalinowego: dźwignię zaworu-krzywkę rozrządu, sworzeń tłokowy-korbowód, czop korbowodu-korbowód (rys. 1). Na wybranych elementach par ślizgowych wykonano warstwy powierzchniowe modyfikowane borem. W parze ślizgowej dźwignia zaworukrzywka rozrządu poddano procesowi borowania dźwignię zaworu, a w układzie sworzeń tłokowy-korbowód borowany był sworzeń tłokowy [9]. Proces borowania obu elementów przeprowadzono w proszku $\left(\mathrm{B}_{4} \mathrm{C}-30 \%, \mathrm{Al}_{2} \mathrm{O}_{3}-68 \%, \mathrm{NH}_{4} \mathrm{Cl}\right.$ i NaF) w temperaturze $950^{\circ} \mathrm{C}$, w ciągu 8 h. Po procesie borowania próbki hartowano izotermicznie. W parze czop korbowodu-korbowód modyfikowano warstwę powierzchniową borem na czopie korbowym za pomocą wiązki laserowej. Warstwę powierzchniową, po pokryciu pastą z borem amorficznym wymieszanym ze szkłem wodnym, przetopiono wiązką laserową (moc wiązki $\mathrm{P}=2 \mathrm{~kW}$, wielkość plamki $\mathrm{d}=4 \mathrm{~mm}$, prędkość obróbki $\mathrm{v}=16 \mathrm{~mm} / \mathrm{s}$, pokrycie ścieżek $\mathrm{f}=0,5 \mathrm{~mm}$, w atmosferze ochronnej argonu). Podczas badań eksploatacyjnych modyfikowane węzły ślizgowe smarowano olejem silnikowym Lotos Syntetic 5W/40.

Badania eksploatacyjne przeprowadzono wykorzystując zespół prądotwórczy wyposażony w jednocylindrowy 4-suwowy silnik gaźnikowy Robin-Subaru EX-17 (moc nominalna 2,6 kW/3000 obr/min, maksymalny moment obrotowy 11,3 N·m/2500 obr/min). Zespół prądotwórczy podczas pracy był obciążony za pomocą elementu oporowego o stałej dopuszczalnej mocy $2000 \mathrm{~W}$. Badania przeprowadzono w cyklu 2000 godzin, obejmującym okresy ciągłej pracy przez 100 godzin i okresy przerwy wynikające z zalecanych terminów okresowej obsługi serwisowej silni- a)

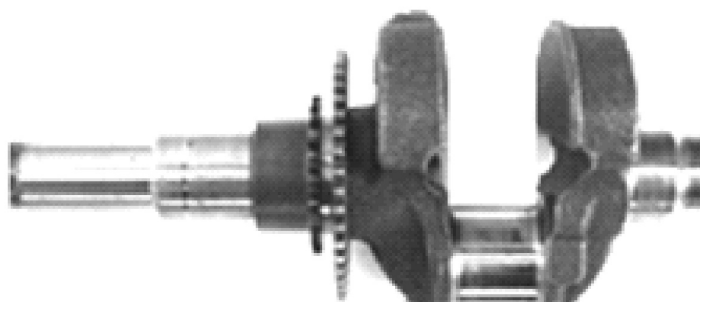

b)

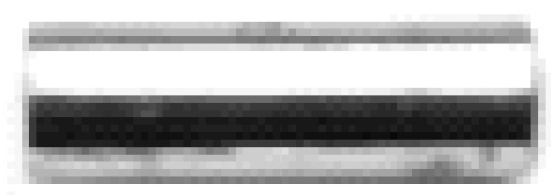

e)

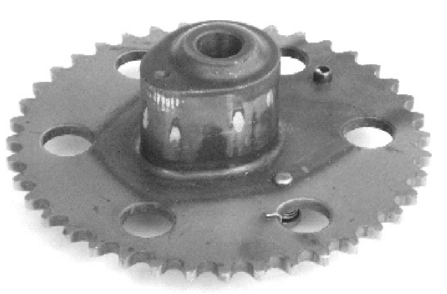

Fig. 1. Elements of sliding pairs of combustion engine: a) crankshaft, b) piston pin, c) rocker arms, d) connecting rod, e) camshaft Rys. 1. Elementy par ciernych silnika spalinowego: a) wał korbowy, b) sworzeń tłokowy, c) dźwignie zaworu, d) korbowód, e) krzywka rozrządu 
combustion engine were performed. In order to determine the intensity of wear of the engine elements, artificial bases were produced on the surface friction. Measurements of the changes of surface roughness and surface scanning were also performed.

\section{Results and discussion}

Application of sliding pairs with the boron-modified elements in the Robin-Subaru EX17 combustion engine caused changes in the geometrical structure of the surface layer of these elements.

Measurements of the arithmetic mean roughness of a surface profile $\mathrm{R}_{\mathrm{a}}$ in the pair rocker arm-camshaft indicated that the pair approached the optimal roughness level for both of the elements. During the friction process, there could be observed a decrease in the value of surface roughness parameter $\mathrm{R}_{\mathrm{a}}$ for both of the cooperating surfaces. The value of the parameter $\mathrm{R}_{\mathrm{a}}$ measured on the camshaft decreased by $250 \%$, on the borided rocker arm by almost $400 \%$, and on the non-borided rocker arm by around 300\%. Significant differences in the initial value of the parameter $\mathrm{R}_{\mathrm{a}}$ between the borided and non-borided rocker arm when the work of the sliding pair had finished, was characterized by the comparable level of surface roughness (Fig. 2).

The results of measurements of the surface roughness parameter $\mathrm{R}_{\mathrm{a}}$ in the sliding pair piston pin-connecting rod small end showed the increase of surface roughness in the pair with the non-borided camshaft (Fig. 3). The value of surface roughness parameter $\mathrm{R}_{\mathrm{a}}$ measured on the non-borided piston pin increased slightly, whereas on the cooperating surface of the hole of connecting rod small end, it increased by $30 \%$. The application of the piston pin with surface layer borided in powder caused slight decrease of its surface roughness. In turn, there was an increase in the value of the parameter $\mathrm{R}_{\mathrm{a}}$ on the sliding surface of the hole of connecting rod small end, but it is by $30 \%$ smaller in proportion to the increase registered in the pair with non-borided piston pin.

After finishing the tests in the sliding pair connecting rod-pin of crankshaft, lower values of surface roughness

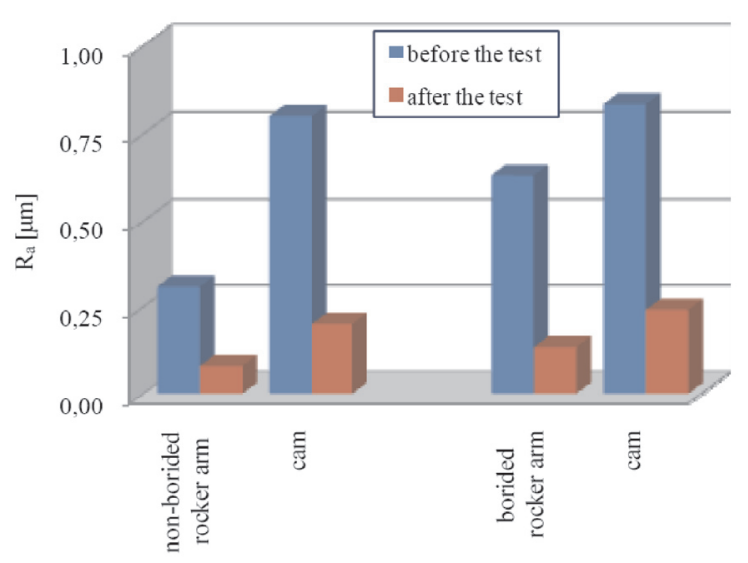

Fig. 2. Change of the arithmetic mean roughness of a surface profile $\mathrm{R}_{\mathrm{a}}$ of elements of sliding pair rocker arm-cam

Rys. 2. Zmiana średniego odchylenia profilu chropowatości powierzchni $R_{a}$ elementów pary dźwignia zaworu-krzywka rozrządu ka. W okresach przerwy na obsługę serwisową po 200, 500, 1000 i 2000 godzinach przeprowadzono pomiary zużycia elementów par ślizgowych silnika spalinowego. Do określenia intensywności zużycia wykorzystano sztuczne bazy wykonane na powierzchniach współpracujących elementów. Przeprowadzono również pomiary zmian chropowatości powierzchni i analizę instrumentalną obszarów zużycia za pomocą mikroskopii skaningowej.

\section{Wyniki badań}

Badania eksploatacyjne węzłów ślizgowych w silniku spalinowym Robin-Subaru EX17 spowodowały istotne zmiany w strukturze geometrycznej warstw powierzchniowych badanych elementów. Pomiary średniego odchylenia profilu chropowatości powierzchni $\mathrm{R}_{\mathrm{a}} \mathrm{w}$ parze dźwignia zaworu-krzywka wykazały, że para dąży do osiągnięcia optymalnego poziomu chropowatości obu elementów składowych. W procesie tarcia obserwuje się obniżenie wartości parametru $\mathrm{R}_{\mathrm{a}}$ obu współpracujących warstw powierzchniowych. Wartość parametru $\mathrm{R}_{\mathrm{a}}$ zmierzona na krzywce uległa zmniejszeniu o ok. 250\%, na dźwigni borowanej prawie o $400 \%$, a na dźwigni nieborowanej ok. 300\%. Znaczne różnice w początkowej wartości R między dźwignią borowaną i nieborowaną, po zakończeniu eksploatacji węzła ślizgowego, charakteryzowały się już zbliżonym poziomem chropowatości powierzchni (rys. 2).

Wyniki pomiarów parametru $\mathrm{R}_{\mathrm{a}} \mathrm{w}$ parze sworzeń tłokowy-otwór główki korbowodu wykazały wzrost wartości chropowatości na powierzchni otworu główki w układzie ze sworzniem nieborowanym (rys. 3). Wartość $\mathrm{R}_{\mathrm{a}}$ zmierzona na sworzniu nieborowanym wzrosła nieznacznie, a na współpracującej powierzchni otworu główki korbowodu wzrosła o 30\%. Zastosowanie sworznia z warstwą powierzchniową borowaną w proszku powoduje nieznaczne zmniejszenie jego chropowatości powierzchni. Natomiast wystąpił wzrost wartości parametru $\mathrm{R}_{\mathrm{a}}$ na powierzchni ślizgowej otworu główki korbowodu, ale jest o $30 \%$ mniejszy w stosunku do wzrostu zarejestrowanego w skojarzeniu ze sworzniem nieborowanym.

Po zakończeniu prób w układzie łożyskowania czop korbowodu-korbowód zaobserwowano mniejsze wartości

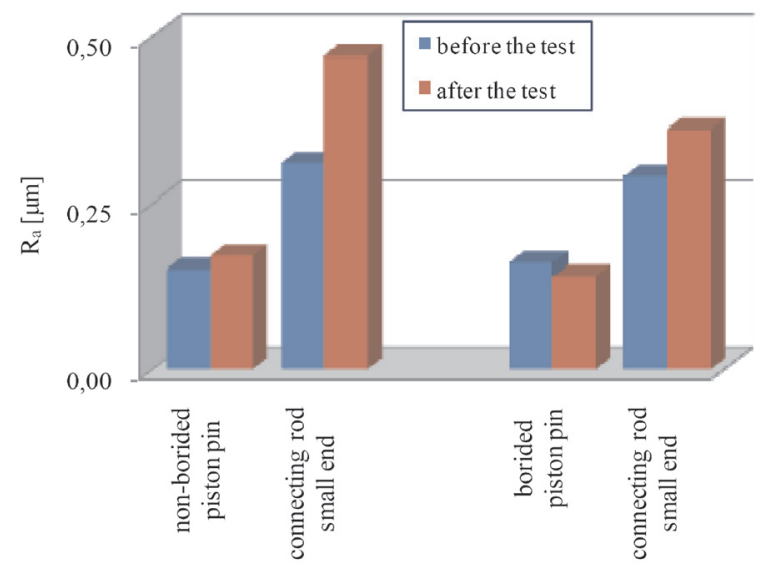

Fig. 3. Change of the arithmetic mean roughness of a surface profile $\mathrm{R}_{\mathrm{a}}$ of elements of sliding pair piston pin-connecting rod small end

Rys. 3. Zmiana średniego odchylenia profilu chropowatości powierzchni $R_{a}$ elementów pary sworzeń tłokowy-otwór główki korbowodu 
parameter $\mathrm{R}_{\mathrm{a}}$ could be observed on the sliding surfaces in the pairs with laser-borided layer (Fig. 4). In the pair in which the pin of crankshaft worked with the borided surface layer, there was an increase in the value of the parameter $R_{a}$ of the crankshaft by $40 \%$, whereas the value of the parameter $\mathrm{R}_{\mathrm{a}}$ of the crankshaft with the non-borided surface layer decreased by $140 \%$. The measurement results of the connecting rod showed larger increase of the value of surface roughness parameter $\mathrm{R}_{\mathrm{a}}$ at the contact with the non-borided pin of crankshaft, than at the contact with the borided pin of crankshaft. The value of the parameter $\mathrm{R}_{\mathrm{a}}$ in the sliding pair with the non-borided surface layer increased by $100 \%$, while in the sliding pair with the non-borided surface layer, it increased by $70 \%$. In turn, the measurements of the sliding surface roughness of the connecting rod cap in both cases revealed comparable values of surface roughness parameter $\mathrm{R}_{\mathrm{a}}$.

The registered changes can be explained by different material composition of the cooperating friction pairs, and different character of loading and type of friction contact. In the pair camshaft-rocker arm, loading has a variable character and the contact is linear. In the later stage of work, the area of contact undergoes change as a result of wear of the surface layers, which leads to the increase of the area of contact and the decrease of the values of unit pressure. These changes have an effect on the change of roughness parameters as a result of wear, which leads to smoothening of the cooperating surface layers and achieving an optimal geometrical structure [10]. In the pair crankshaft-connecting rod, changes are generated mainly as a result of the sliding speed of the crankshaft on the surface of the connecting rod and the variable character of loading. The value of loading and its direction results from the loading caused by combustion pressure and the inertia forces of the elements of the set: connecting rod- crankshaft. Loading variables cause an uneven contact between surface peaks of the cooperating surface layers, which leads, for the most part, to the wear of the bearing alloy. The products of wear, including very hard oxides, also lead to the wear of the pin of crankshaft material. The increased roughness parameters of the non-borided surface are also the result of its smaller hardness. On the other hand, changes in the value of surface roughness parameter $\mathrm{R}_{\mathrm{a}}$ in the connecting rod cap are the effects of loadings generated by the inertia force, which in the work cycle of the engine take on lower values, and their run is less dynamic. These changes involve mainly the piston pin. In the case of the pin of crankshaft, the increase in roughness could have been caused by laser treatment, which may have led to the heterogenic layout of hardness on the length of the pin of crankshaft. These changes may have caused more intensive wear of the parts of smaller hardness, and the products of wear intensified the process of wear and the changes in the geometrical structure of the sliding pair [11].

The measurements of wear of the elements of friction pairs in the combustion engine proved that modification of the surface layers with boron has an impact on the process of wear and its intensity. The measurement of wear of the rocker arm made during the process of the engine operation parametru $\mathrm{R}_{\mathrm{a}}$ na powierzchniach ślizgowych w skojarzeniach $\mathrm{z}$ warstwą borowaną laserowo (rys. 4). W skojarzeniu, w którym pracował czop z warstwą powierzchniową borowaną, wystąpił wzrost wartości parametru $\mathrm{R}_{\mathrm{a}}$ czopa o 40\%, zaś wartość parametru $\mathrm{R}_{\mathrm{a}}$ czopa $\mathrm{z}$ warstwą powierzchniową nieborowaną pogorszyła się o $140 \%$. Wyniki pomiaru

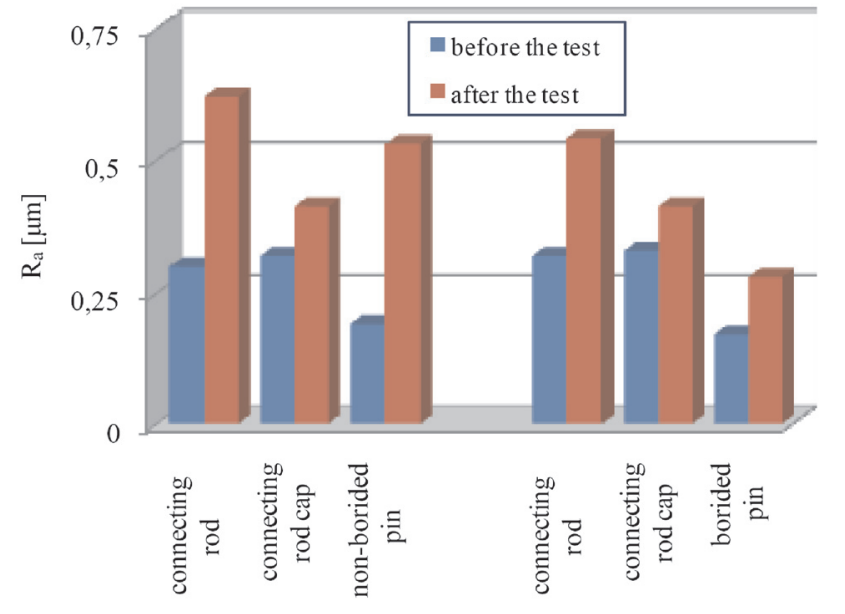

Fig. 4. Change of the arithmetic mean roughness of a surface profile $\mathrm{R}_{\mathrm{a}}$ of elements of sliding pair pin of camshaft-connecting rod

Rys. 4. Zmiana średniego odchylenia profilu chropowatości powierzchni $R_{a}$ elementów pary czop korbowy-korbowód

korbowodu wykazały większy wzrost wartości parametru $\mathrm{R}_{\mathrm{a}} \mathrm{W}$ styku z czopem nieborowanym, niż w styku z czopem borowanym. Wartość parametru $\mathrm{R}_{\mathrm{a}} \mathrm{W}$ skojarzeniu $\mathrm{z}$ warstwą powierzchniową nieborowaną wzrosła o $100 \%$, a w skojarzeniu z warstwą borowaną wzrosła o 70\%. Natomiast pomiary chropowatości powierzchni ślizgowej stopy korbowodu wykazały w obu przypadkach zbliżone wartości parametru $R_{a}$.

Zarejestrowane zmiany można tłumaczyć inną kompozycją materiałową współpracujących węzłów ciernych, jak również innym charakterem obciążenia i rodzajem styku ciernego. W parze krzywka wałka rozrządu-dźwignia zaworu obciążenie ma charakter zmienny, a styk jest liniowy. W późniejszym etapie pracy ulega zmianie pole styku w wyniku zużycia warstw powierzchniowych, co prowadzi do zwiększenia powierzchni styku i zmniejszenia wartości nacisków jednostkowych. Zmiany te wpływają na zmianę parametrów chropowatości w wyniku zużycia ściernego, co prowadzi do wygładzenia współpracujących warstw powierzchniowych i osiągnięcia optymalnej struktury geometrycznej [10]. W parze czopa i korbowodu zmiany głównie generowane są w wyniku prędkości ślizgania się czopa po powierzchni korbowodu oraz zmiennego charakteru obciążenia. Wartość obciążenia i kierunek jego działania wynikają z przebiegu siły nacisku wywołanej rozprężającymi się gazami po spaleniu mieszanki i siłami bezwładności elementów pary tłok-korbowód-wał korbowy. Zmienne obciążenia powodują występowanie styków nierówności współpracujących powierzchni, co prowadzi do zużycia głównie materiału panwi. Produkty zużycia, w tym bardzo twarde tlenki, powodują 
showed that the application of the process of boronizing in powder significantly decreased its wear (Fig. 5). The application of borided rocker arm caused the decrease of wear by three times in proportion to the non-borided rocker arm, and the depth of scar reached the value of $0.017 \mathrm{~mm}$. In turn, the wear of the non-borided rocker arm is characterized by a larger increase of wear with the runtime of the test; as the final result, the depth of scar reached the value of $0.07 \mathrm{~mm}$ (Fig. 6). The linear wear of camshaft cooperating with the rocker arm amounted to $0.08 \mathrm{~mm}$ after the test had been finished.

The registered wear during the engine test in the pair pin of crankshaft-connecting rod showed that the application of laser boronizing in the treatment of the pin of crankshaft sur-

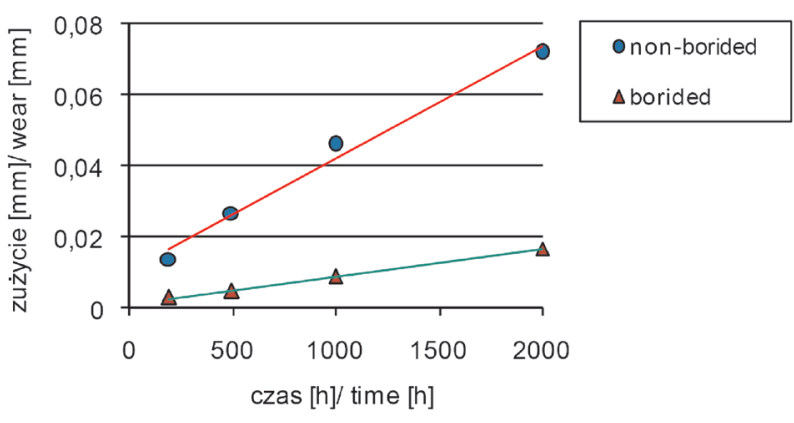

Fig. 5. Linear wear of rocker arm

Rys. 5. Zużycie liniowe dźwigni zaworowej

face layer has an impact on the increase of wear of the softer material of the connecting rod (Fig. 7). The borided pin of crankshaft causes the increase of wear of the connecting rod material by around $45 \%$, and the wear of the connecting rod cap material increases by $30 \%$. In the friction pair with the non-borided pin of crankshaft, the wear of the connecting rod and the connecting rod cap are at the comparable level. The application of the laser boronizing process caused the wear of the connecting rod material to be larger than the wear of the connecting rod cap material. The changes of wear stem from the character of loading and heterogeneity of the borided layer. The surface layer of the pin of crankshaft formed in the process of laser boronizing treatment is characterized również zużycie materiału czopa. Zwiększone parametry chropowatości nieborowanej powierzchni są wynikiem jej mniejszej twardości, a znaczna różnica w chropowatości końcowej może być również efektem wypełnienia nieciągłości w warstwie borowanej proszkowo przez materiał korbowodu. Zmiany te dotyczą głównie sworznia; w przypadku czopa wzrost chropowatości może być spowodowany obróbką laserową, która wprowadziła niejednorodny rozkład twardości na długości czopa. Zmiany te mogły wywoływać intensywniejsze zużycie w częściach o mniejszej twardości, a produkty zużycia intensyfikowały proces zużycia i zmiany w strukturze geometrycznej pary ślizgowej [11].

Pomiary zużycia elementów par ciernych silnika spalinowego dowiodły, że modyfikacja borem warstw powierzchniowych wpływa na przebieg procesu zużycia i jego wielkość. Wyniki pomiarów zużycia dźwigni zaworowej wykonane w trakcie badań silnika wykazały, że zastosowanie procesu borowania w proszku w sposób istotny zmniejszyło jej zużycie (rys. 5). Zastosowanie borowania warstwy powierzchniowej dźwigni spowodowało prawie trzykrotne zmniejszenie zużycia w stosunku do dźwigni nieborowanej, a głębokość wytarcia osiągnęła wartość $0,017 \mathrm{~mm}$. Natomiast zużycie dźwigni nieborowanej charakteryzuje się większym przyrostem zużycia wraz z upływem czasu trwania próby; w efekcie końcowym głębokość wytarcia osiągnęła wartość 0,07 mm (rys. 6). Zużycie liniowe krzywki współpracującej z dźwigniami zaworów po zakończeniu prób wyniosło $0,08 \mathrm{~mm}$.

Rejestrowane zużycie podczas trwania próby eksploatacyjnej w parze czop korbowy-korbowód wykazało, że zastosowanie borowania laserowego do obróbki warstwy powierzchniowej czopa wpływa na zwiększenie zużycia miększego materiału korbowodu (rys. 7). Borowany czop powoduje wzrost zużycia materiału korbowodu o ok. $45 \%$, a zużycie materiału stopy korbowodu zwiększa się o $30 \%$. W parze ciernej z czopem nieborowanym zużycie materiałów korbowodu i stopy korbowodu jest na zbliżonym poziomie. Zmiany w wielkości zużycia wynikają z charakteru obciążenia oraz niejednorodności warstwy borowanej. Ukształtowaną w procesie borowania laserowego warstwę powierzchniową czopa w przekroju wzdłużnym charakteryzuje zmienna mikrotwardość i niejednorodna

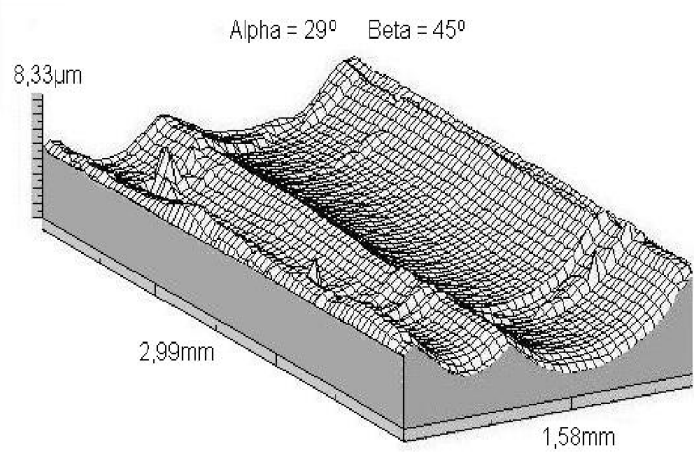

b)

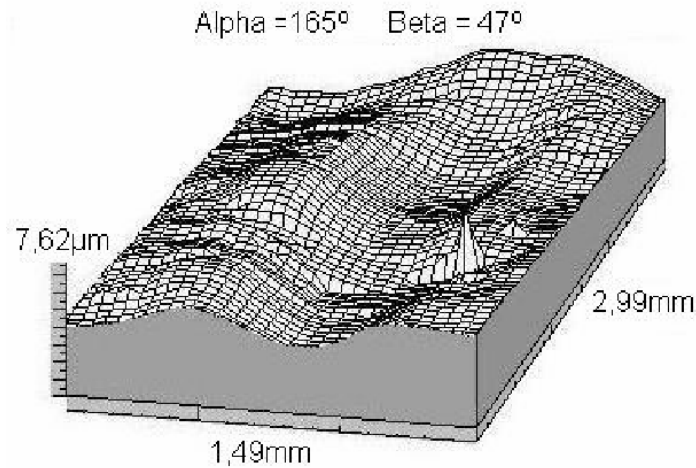

Fig. 6. Wear scar on the rocker arms: a) non-borided rocker arm, b) borided rocker arm Rys. 6. Ślady wytarcia na dźwigniach zaworowych: a) dźwignia nieborowana, b) dźwignia borowana 
in the longitudinal cut by a variable microhardness and heterogenic structure. It has an influence on the occurrence of the areas of contact which differ from each other in the intensity of friction processes and the increased possibility of the formation of adhesive bonds. As a result of variable loading and insufficient lubrication, the processes of wear may have become intensified wear under the influence of the products of wear which came into existence during the friction processes. The difference in wear of the connecting rod material and the connecting rod cap resulted from the different loading conditions in the case of those two elements, which was presented in the description of surface roughness of this friction, including works $[11,12]$.

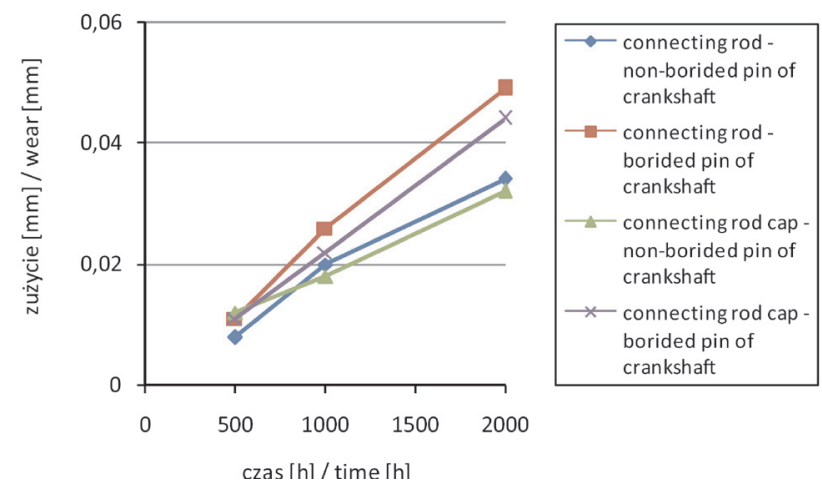

Fig. 7. Wear of connecting rod and connecting rod cap depending on surface treatment of pin crankshaft

Rys. 7. Zużycie liniowe korbowodu i stopy korbowodu w zależności od wykonanej obróbki warstwy powierzchniowej czopa

The analysis of the areas of wear using the scanning microscopy SEM/EDS indicated the handling of materials in the areas of friction of the rocker arm and camshaft. The obtained pictures of the representative areas of wear of the camshaft demonstrated significant differences in the surface layer of the cooperating elements. Scanning of the camshaft surface revealed the occurrence of inclusions on the sliding surface consisting of boron with the presence of iron and copper. (Fig. 8). The distribution of inclusions attests to the handling of boron onto the surface of the camshaft from the surface layer of the rocker arm. The character of the distribution is incidental, and the largeness of inclusions is diverse - from very small dots to larger areas of irregular shape. The analysis of the chemical elements showed that, for the most part, the inclusions consisted of boron, and it oscillates between $61-97 \%$. On the surface of the camshaft there appeared also atoms of sulphur, which were evenly distributed on the steel surface of friction. The registered presence of copper in the analysis of the chemical elements is the effect of its handling from the connecting rod material, where it is the alloying element. The main presence of copper is observed in the area of the steel sliding surface, whereas in the area of inclusions its portion is smaller and it decreases with the increase of the content of boron.

\section{Conclusions}

The conducted measurements of the elements of the combustion engine after the tests and the analysis of the obtained results allow for the formulation of the following conclusions: struktura. Wpływa to na występowanie obszarów styków różniących się intensywnością procesów tarcia i zwiększoną możliwością powstawania szczepień adhezyjnych. W wyniku zmiennych obciążeń i niedostatecznego smarowania procesy zużycia mogą ulegać intensyfikacji i generować zużycie pod wpływem produktów zużycia powstałych w procesie tarcia. Różnica w zużyciu materiałów korbowodu i stopy korbowodu jest efektem zróżnicowania warunków obciążenia obu elementów, co zostało przedstawione przy opisie zmian chropowatości powierzchni tego skojarzenia m.in. w pracach $[11,12]$.

Analiza obszarów zużycia za pomocą mikroskopii skaningowej SEM/EDS wskazała na ,przenoszenie” materiałów w obszarze tarcia dźwigni zaworowej i krzywki rozrządu. Uzyskane obrazy reprezentatywnych obszarów zużycia krzywki rozrządu wykazały istotne różnice w warstwie powierzchniowej współpracujących elementów. Skaning powierzchni krzywki rozrządu ujawnił występowanie wydzieleń na powierzchni ślizgowej składających się z boru wraz z udziałem siarki i miedzi (rys. 8). Rozkład wydzieleń świadczy o przenoszeniu się boru na powierzchnię krzywki rozrządu z warstwy powierzchniowej dźwigni zaworowej. Charakter rozmieszczenia jest przypadkowy, a wielkość wydzieleń jest różna - od bardzo małych kropek do większych obszarów o nieregularnym kształcie. Analiza składu pierwiastków wykazała, że wydzielenia te składają się głównie $\mathrm{z}$ boru, a jego udział masowy waha się w granicach 61-97\%. Na powierzchni krzywki rozrządu występowały również atomy siarki, które były równomiernie rozłożone na stalowej powierzchni tarcia. W obszarze wydzieleń boru udział siarki na powierzchni ślizgowej zmniejsza się lub nie występuje. Zarejestrowano również obecność miedzi, co jest efektem przeniesienia jej z materiału korbowodu,
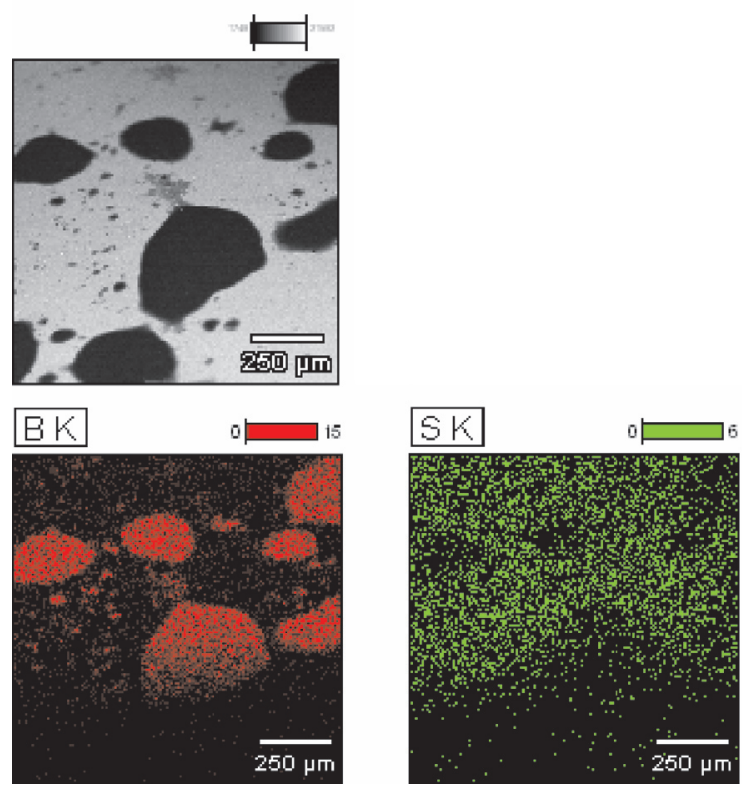

Fig. 8. Photo of friction area of camshaft and mapping of distribution atoms boron and sulphur

Rys. 8. Fotografia obszaru tarcia krzywki rozrzadu oraz mapy rozkładu atomów boru i siarki 
1. The surface roughness formed in the friction pair depends on the initial roughness, friction conditions, and the applied surface treatment. The registered trends do not lead to the decrease of surface roughness, but instead they are conducive to the formation of the optimal geometrical structure for a given pair. In the pair: camshaft-rocker arm, surface roughness has decreased, whereas in the pair: piston pin-connecting rod-pin of crankshaft an increase has occurred. A significant increase of surface roughness concerns mainly the material of connecting rod in the pair with the non-borided surface layer of pin.

2. Measurements of wear of the elements of the combustion engine showed that the process of boronizing has an important influence on the decrease of wear of the borided element of the friction pair: the wear of the rocker arm pack-borided is smaller in proportion to the non-borided one by $350 \%$. The measurements of wear of the connecting rod, in turn, showed an increase of wear at the contact with the laser-borided surface layer, but no definitive wear can be established; the wear of the connecting rod is larger than the wear of the connecting rod cap, with a comparable wear of both elements in the pair with the non-borided element.

3. The registered changes of the surface geometry and the wear of the combustion engine elements are the results of the character of loading, different for each tested pair, different kinematics of the cooperation of the elements of friction pairs, as well as different material composition and the applied method of modification of the surface layer with boron.

\section{Bibliography/Literatura}

[1] Bayrakceken H., Ucun I., Tasgetiren S.: Fracture analysis of a camshaft made from nodular coast iron. Engineering Failure Analysis, 12, pp. 1240-1245, 2006.

[2] Sen U., Sen S., Yilmaz F.: Structural characterizations of boride layer on boronized ductile irons. Surface Coating and Technology, 176, pp. 223-228, 2000.

[3] Kulka M., Pertek A.: The importance of carbon content beneath iron borides after boriding of chromium and nickel-based low carbon steel. Applied Surface Science, 214, pp. 161-171, 2003.

[4] Sen U., Sen S., Yilmaz F.: The fracture toughness of borides formed on boronized cold work tool steel. Material Characterization, 50, pp. 261-267, 2003.

[5] Bejar M.A., Moreno E.: Abrasive wear resistance of boronized carbon and low-alloy stell. Journal of Materials Processing Technology, 173, pp. 352-358, 2006.

[6] Martini C., Palombarini G., Poli G., Prandstraller D.: Sliding and abrasive wear behaviour of boride coatings. Wear, 256, pp. 608-613, 2004.

[7] Atik E., Yunker U., Meric C.: The effect of conventional heat treatment and boronizing on abrasive wear and corrosion of SAE 1010, SAE 1040, D2 and 304 steels. Tribology International, 36, pp. 2003, 155-161.

[8] Lubas V:: Tribological properties of surface layer with boron in friction pairs. Surface Review and Letters, 16, pp. 767-773, 2009.

[9] Service manual models EX13, 17, 21, 27 engines, Robin America. Inc, 2002.

[10] Guha V., Chowdhuri V.: The effect of surface roughness on the temperature at the contact between sliding bodies. Wear, 197, pp. 63-73, 1996. gdzie jest pierwiastkiem stopowym. Główny udział miedzi rejestrowany jest w obszarze stalowej warstwy ślizgowej, natomiast w obszarze wydzieleń udział miedzi jest mniejszy i maleje wraz ze wzrostem zawartości boru.

\section{Wnioski}

Przeprowadzone pomiary elementów silnika spalinowego w ramach przyjętego programu badań i analiza uzyskanych wyników pozwalają na sformułowanie następujących wniosków:

1. Ukształtowana w parze ciernej chropowatość powierzchni zależy od chropowatości początkowej, warunków tarcia i zastosowanej obróbki powierzchniowej. Rejestrowane trendy nie prowadzą do zmniejszenia chropowatości, ale do kształtowania optymalnej struktury geometrycznej dla danego skojarzenia. W parze krzywka-dźwignia zaworu chropowatość powierzchni zmniejszyła się, natomiast w układzie sworzeń tłoka-korbowód-czop korbowy wystąpił jej wzrost. Istotny przyrost chropowatości dotyczy głównie materiału korbowodu w skojarzeniu z nieborowaną warstwą powierzchniową czopa.

2. Pomiary zużycia elementów silnika spalinowego wykazały, że borowanie wpływa znacząco na zmniejszenie zużycia borowanego elementu pary ciernej: zużycie borowanej w proszku dźwigni zaworu jest o ok. $350 \%$ mniejsze w stosunku do nieborowanej. Pomiary zużycia korbowodu wykazały natomiast wzrost zużycia w kontakcie z warstwą borowaną laserowo, ale nie można wyznaczyć jednoznacznego związku; zużycie korbowodu jest większe niż zużycie stopy korbowodu, przy zbliżonym zużyciu obu elementów w skojarzeniu z nieborowanym elementem.

3. Rejestrowane zmiany geometrii powierzchni i zużycia elementów silnika spalinowego są wynikiem charakteru obciążenia, odmiennego dla każdej badanej pary, innej kinematyki współpracy elementów pary ślizgowej, jak również odmiennej kompozycji materiałowej i zastosowanej metody modyfikacji borem warstwy powierzchniowej.

Paper reviewed/Artykut recenzowany

[11] Kuhlmann-Wilsdorf V.: Effects of local high pressure and extreme shears at tribological contact spots. Tribology and Interface Engineering Series, 39, pp. 417-428, 2001.

[12] Schouwenaars V., Jacobo V., Ortiz A.: Microstructure aspect of wear in soft tribological alloys. Wear, 263, pp. 727-735, 2007.

Prof. Kazimierz Lejda DSc., DEng. - Professor in the Faculty of Mechanical Engineering and Aeronautics at the Rzeszow University of Technology.

Prof. dr hab. inż. Kazimierz Lejda - profesor na Wydziale Budowy Maszyn i Lotnictwa Politechniki Rzeszowskiej.

e-mail: klejda@prz.edu.pl

Mr. Janusz Lubas, DEng. - doctor in the Institute of Technology at the University of Rzeszow.

Dr inż. Janusz Lubas - adiunkt w Instytucie Techniki Uniwersytetu Rzeszowskiego.

e-mail: janas@univ.rzeszow.pl
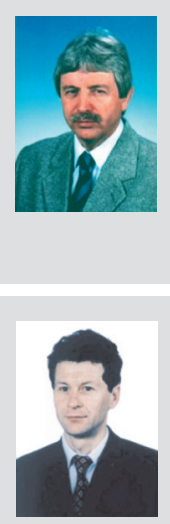